\title{
Archetypal Orientations of Mind in Historical Jesus Thought
}

\author{
Herman J Pietersen
}

\author{
Professor, University of Limpopo, Turfloop Campus 0727, Republic of South Africa
} herman.pietersen@ul.ac.za

Doi:10.5901/mjss.2014.v5n23p2035

\section{Abstract}

In the current paper a previously developed theory of fundamental orientations or modalities of mind is presented, together with a condensed overview of the nature and characteristics of historical Jesus thought. The aim is to demonstrate the applicability of the theory to various depictions of the historical Jesus. The paper focuses on historical Jesus research representative of each of the four archetypal orientations of the mind (types I, II, III and IV). For this purpose appropriate Biblical evidence and the ideas of some leading figures in the field of historical Jesus research are briefly surveyed. The general tendency in the scholarly literature, in which recourse is also taken to how Jesus thought about himself and how he was regarded by his contemporaries, indicate four distinct roles pointing to him as prophet (type I), teacher-Rabbi (type II), healer (type III), and Messiah/king (type IV).

Keywords: Archetypal orientations, prophet, teacher, healer, Messiah.

\section{Introduction}

\subsection{Basic approaches in human thought}

The meta-theory to be utilized here was developed in detail in a first volume (Pietersen, 2011) and continued with new applications in a second volume, (Pietersen, 2014) and will therefore only briefly be discussed.

Figure 1 shows four orientations in human thought that are the result of a combination of two axes (epistemological and ontological), namely: objectivist-empyrean (type I); objectivist-empiricist (type II); subjectivist-empiricist (type III), and the subjectivist-empyrean (type IV).

This is followed in Figures 2, 3, 4 and 5 by a description of characteristic elements of each of the four archetypes. These should be more or less self-explanatory, but it may be helpful to point out that each of the primary orientations address a different and basic question, namely: (a) what is this? (Type II); (b) what is behind this? (Type I); (c) what is wrong / wonderful about this? what is the story? (Type III); (d) what should be done about this? (Type IV).

Figure 1: The four orientations in human thought

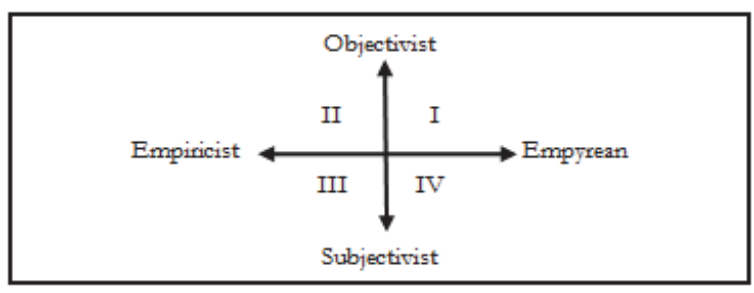

Figure 2: Objectivist-empyrean (type I) elements

\begin{tabular}{ll|} 
Emphasize reason (rationality) \\
Impersonal \\
Theoretical/integrative \\
Macroscopic focus \\
Comprehensive understanding \\
Concerned with possible ideas \\
\hline
\end{tabular}


Figure 3: Objectivist-empiricist (type II) elements

\begin{tabular}{l} 
Emphasize reason (rationality) \\
Impersonal \\
Systematic-analytic \\
Microscopic focus \\
Detailed explanation \\
Concerned with verifiable ideas \\
\hline
\end{tabular}

Figure 4: Subjectivist-empiricist (type III) elements

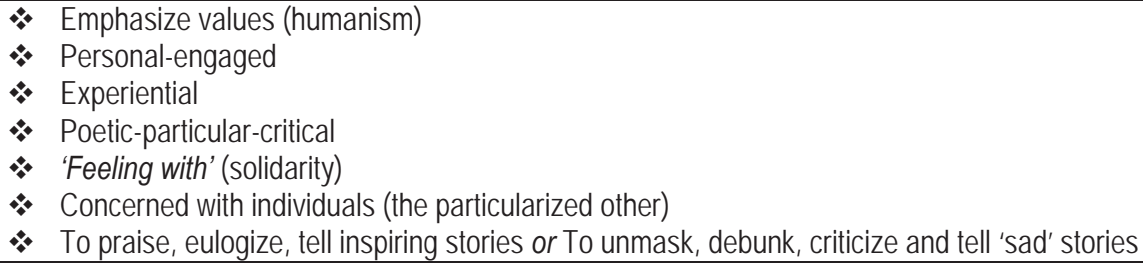

Figure 5: Subjectivist-empyrean (type IV) elements

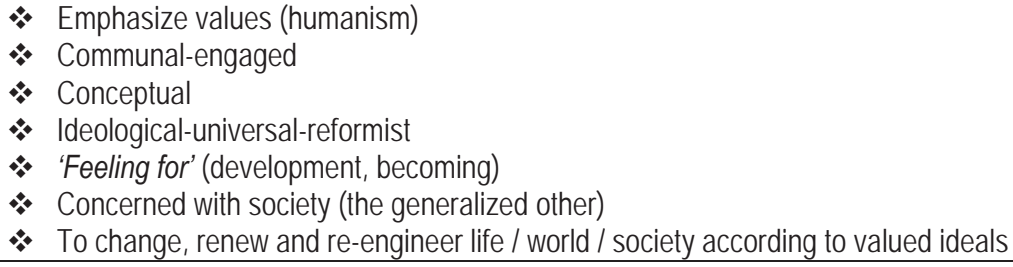

\subsection{The main principles}

The main propositions or theses of the meta-theory are as follows (Pietersen, 2011):

a) Fundamental orientations of mind predetermine the type of ideas, theories, "ways" of making sense of and dealing with the world.

b) Each orientation or modality of mind co-exists with other modes in a dynamic mutuality of conflict and complementariness.

c) Thought products (individually or collectively) reflect different mixes of the basic orientations, although dominant (primary) tendencies prevail as a result of root "preferences". No thinker functions entirely within a single (primary) mode of thought, but also in varying degrees interfaces with directly adjacent (secondary) modes. Tertiary orientations also manifest in each intellectual product, either in a conflicting, suppressed or underrepresented manner.

d) Together, the different modes of thought form a unity or whole with each giving meaning to the other and with each dependent on the existence of its opposite mode.

e) Attempted dominance by one modality of mind inevitably leads to countervailing reactions in other realms of thought. Adherents of highly divergent (directly opposing) orientations will more likely experience mutual misunderstanding, disaffection and even potentially irreconcilable beliefs and convictions.

f) Knowledge endeavours in the world at large, in different cultures, disciplines and traditions of thought, and at different levels of analysis, show similarity in terms of underlying modalities of mind.

g) The limitations of one modality of mind are complemented by the strengths of others, especially its diagonally opposite mode.

\section{Historical Jesus Thought: An Overview}

The modern historical Jesus literature is rife with disparate views and interpretations, based on a wide range of different combinations of, and selections from, both canonical (biblical) and non-canonical source materials. The situation is 
complicated by different meanings being attached to the content of these source materials and by opposing methodological approaches, especially the use of so-called criteria of authenticity, on which there seems to be no general consensus. In this regard some criticism is expressed as follows:

- The use of the criterion of 'multiples attestation' (namely: "...that if the same material is found in two or more independent sources, that material must be older than the sources in which it is found, and is consequently more likely to go back to the historical Jesus," (Eve, 2005: 26), gives a deceptive appearance of 'scientific objectivity';

- The use of the concepts 'authentic' and 'inauthentic' are questionable, and should be replaced with an emphasis on the 'interpretation of historical traditions.' (Rodriguez, 2009: 152).

One scholar expresses the situation in historical Jesus research as follows: "At the end of the 19th century Jesus was Adolph von Harnack's teacher of 'the fatherhood of God and the brotherhood of mankind'; in the early years of the 20th century Albert Schweitzer's despairing Messiah; in the '30s, Rudolf Bultmann's preacher of obedience. Now, after another generation of New Testament scholars has produced its portraits, Jesus has become many things eschatological prophet, 'marginal Jew,' magician, secular sage..." (Harvey, 2000: 91). A recent, major review of international scholarship concludes that: "A side effect of this otherwise very enriching pluralism has been the difficulty (if not the impossibility) to reach any kind of consensus on almost every point under discussion." (Bertalotto, 2010: 251)

By way of analogy, one finds that the field is also subject to a sort of geological fault-line split between the Christ of Faith and the Jesus of history, or, what one leading scholar categorizes as a distinction between the 'pre-Easter Jesus' of history and the 'post-Easter Jesus' of faith (Borg, 1994: 195). In this regard the situation over the past two hundred years is summarised as follows: "...scholarship in the nineteenth century generally affirmed the Jesus of history (and thus the theological importance of the historical study of Jesus) and in much of the twentieth century affirmed the Christ of faith (and hence the theological unimportance of historical Jesus scholarship)... The last few decades have seen an increasing separation between historical Jesus scholarship and systematic theology (including christology) as intellectual disciplines, and a corresponding separation of historical Jesus scholarship from an explicitly Christian theological agenda. (Borg, 1994: 188).

That the situation is more varied that a mere separation of historical Jesus research into two camps is, however, shown in the observation that: "Current Historical Jesus research is characterized by a deep-seated struggle and conflict between critical Jesus research and the orthodox Christian position, on the one hand, and, on the other, within Jesus research itself between the critical and the orthodox positions. (Craffert, 2008: 266)

The current trend in historical Jesus studies is one of taking an interest in a more broadly-based 'scientific' (hypothesis-verification) approach, increasingly making use of concepts and findings from various sciences and scholarly disciplines, such as archaeology and anthropology, in trying to flesh out the socio-historical context of the historical Jesus, away from the previous focus on Jesus as individual personality, as such.

The literature typically distinguishes between three stages in the study of and writing about the historical Jesus, namely: the "old or first quest" which dominated $19^{\text {th }}$ century historical life of Jesus studies and came to an end with the renowned New Testament scholar, Rudolph Bultmann's verdict that: "I do indeed think that we can now know almost nothing concerning the life and personality of Jesus, since the early Christian sources show no interest in either, are moreover fragmentary and often legendary... (Bultmann, 1934: 9). Bultmann, for his part, was persuaded by Albert Schweitzer's influential earlier work, The Quest of the Historical Jesus, in which the latter concluded that: "There is nothing more negative than the result of the critical study of the Life of Jesus... The Jesus of Nazareth who came forward publicly as the Messiah, who preached the ethic of the Kingdom of God, who founded the Kingdom of Heaven upon earth, and died to give His work its final consecration, never had any existence. He is a figure designed by rationalism, endowed with life by liberalism, and clothed by modern theology in an historical garb." (Schweitzer, 1948: 399).

Thus Schweitzer was, in effect, saying that all enquirers into the historical Jesus are engaged in a fruitless search, chasing after a phantom, a personage about whom little is and can be known for certain and who forever after his death became an enigma to later generations. His advice to all questers was to give up the search for the historical Jesus, to stop questing after what Strauss considered to be a mere legendary figure. Bultmann promptly followed Schweitzer.

The so-called "new or second quest" was started by some of Bultmann's students (notably Ernst Kaesemann) and given further impetus, in the 1950s by the work of James Robinson. This phase was followed (in the 1980s) by Robert Funk's establishment of the so-called Jesus Seminar, whose aim was to 'scientifically' determine the authenticity of all the biblical sayings of Jesus. The membership of this group, inter alia, came (by a system of voting) to a decision that the 'fact' that: "... at least $18 \%$ of the sayings are authentic does not mean they are the actual words of Jesus, but that they preserve the gist of Jesus' message in a way that makes those sayings recognizable as deriving from him and not from the early church or the Evangelists." (McGaughy, 1996: 12). 
Currently a 'third quest' predominates. This stage is characterized as follows: "...It has no coordinated program. It does not seem to be bothered by the problem of continuity between Jesus and the kerygma. It seems little concerned with the problem of criteria for authenticity. Sometimes it pays more attention to the deeds of Jesus rather than to his sayings, though this is notably not the case with some of its chief practitioners. Its major feature is that it attempts to place Jesus firmly into the social and cultural context of his environment, especially in first-century Galilee. It is largely if not exclusively an American enterprise." (Fuller, 1994: 164; see also Keck, 1994: 784).

Bertalotto (2010: 252) identifies the following commonalities or agreements in historical Jesus research:

> An acceptance that historical Jesus studies should accommodate but not be 'dictated by theological concerns';

$>$ The central importance of the Jewishness of Jesus;

> Greater recourse to 'contributions from the social sciences and archaeology';

$>$ Acknowledgement of 'the deep involvement of Jesus in the cultural and religious debate of his time'

$>$ The need for 'a new model of scholarship'.

\section{Archetypal Orientations in Historical Jesus thought}

One of the most common aspects of the historical Jesus literature is the ubiquitous reference, by almost all scholars, to Jesus as being prophet, teacher, healer, as well as Messiah (king), all in one (see Figure 6 below). It is, for instance, acknowledged:

$>$ That Jesus was each of these is attested by recurring motifs and themes that permeate the Gospel narratives, found in multiple sources and forms. (Borg, 1988: 291);

$>$ That the principal difficulty in attempting to classify or categorize Jesus is that he exhibited characteristics of several categories and the categories themselves overlap. (Evans, 2011: 243).

Figure 6: Paradigmatic conceptions of Jesus

\begin{tabular}{|l|l|}
\hline TYPE II & TYPE I \\
Wisdom Teacher/Rabbi & Prophet \\
(Strauss, Renan, Bultmann) & (Strauss, Bultmann ) \\
Borg (1988): Sage & Borg (1988): Prophet \\
Borg (1994): Teacher of wisdom & Borg (1994): Social prophet \\
Evans (2011): Sage / Rabbi & Evans (2011): Prophet \\
\hline TYPE III & TYPE IV \\
Healer-Charismatic & Commanding Messiah \\
(Strauss, Vermes) & (Strauss, Renan, Schweitzer) \\
Borg (1988, p291): Charismatic 'holy man' & Borg (1988): Revitalization movement founder \\
Borg (1994, p30): Spirit person & Borg (1994): Revitalization movement founder \\
Evans (2011): Healer & Evans (2011): Messiah \\
\hline
\end{tabular}

\subsection{The visionary prophet (Type I)}

The following scholars describe or put emphasis on the historical Jesus as prophet (with some variation, namely, as eschatological prophet, messianic prophet, and as country prophet): Strauss (1835); Renan (1863); Bultmann (1934); Meier (in Willits, 2005); Allison (in Willits, 2005); Charlesworth (in Bertalotto, 2010); Chilton (in Bertalotto, 2010); Freyne (in Bertalotto, 2010); Oporto (in Bertalotto, 2010); McKnight (in Bertalotto, 2010). The Biblical evidence for Jesus as prophet can be found in many places in the New Testament. Figure 7 provides some examples.

Figure 7: Biblical evidence for Jesus as Prophet (Type I)

The second prediction of the passion:

Mt: 17:22: And while they abode in Galilee, Jesus said...The Son of man shall be betrayed into the hands of men. Mt: 17:23: And they shall kill him, and the third day he shall be raised again.

The prediction of the destruction of Jerusalem:

Mt: 24:1: And Jesus went out, and departed from the temple: and his disciples came to him for to shew him the buildings of the temple.

Mt: 24:2: And Jesus said unto them, See ye not all these things? verily I say unto you, There shall not be left here one stone upon another, that shall not be thrown down. 


The prediction of false prophets:
Mk: 13:6: For many shall come in my name, saying, I am Christ; and shall deceive many.
Mk: 13:8: For nation shall rise against nation, and kingdom against kingdom: and there shall be earthquakes in
divers places, and there shall be famines and troubles: these are the beginnings of sorrows.
The betrayal of Jesus:
Mt: 26:21: And as they did eat, he said, Verily I say unto you, that one of you shall betray me.

Figure 8 briefly highlights the preference for Jesus as prophet of one kind or another by historical Jesus scholars.

Figure 8: Some proponents of Jesus as Prophet

\begin{tabular}{|l|}
\hline "An unbiased reading of the Synoptic evidence reveals that sympathetic witnesses of his Galilean activity recognized \\
Jesus as either John the Baptist, Elijah or a prophet..." (Vermes, 1973: 87) \\
\hline "...I distinguish between a historical Jesus prophet, according to several biblical typologies, and a paschal Jesus Messiah, \\
with the paschal extension of Prophet-Teacher 'like Moses"' (Croatto, 2005: 451) \\
\hline "...the understanding of Jesus as a (ethical-eschatological) social prophet should be taken seriously." (van Eck, 2009: 1) \\
\hline "... arguments for the concept of an eschatological prophet as an early root model for christological development, based \\
primarily on traditions from the Synoptic Gospels." (Kazen, 2008: 593)
\end{tabular}

\subsection{The teacher-priest (Type II)}

The following scholars describe or put emphasis on the historical Jesus as teacher: Renan (1863); Bultmann's (1934); Borg's (1993); Meier (in Willits, 2005); Allison (in Bertalotto, 2010); Levine (in Bertalotto, 2010). Figure 9 provides some Biblical evidence for Jesus as teacher.

Figure 9: Biblical evidence of Jesus as Teacher (Type II)
Parable of House on rock or sand:
Mt: 7:24: Therefore whosoever heareth these sayings of mine, and doeth them, I will liken him unto a wise man, which built his house upon a rock:
Mt: 7:25: And the rain descended, and the floods came, and the winds blew, and beat upon that house; and it fell not: for it was founded upon a rock.
Mt: 7:26: And every one that heareth these sayings of mine, and doeth them not, shall be likened unto a foolish man, which built his house upon the sand:
Mt: 7:27: And the rain descended, and the floods came, and the winds blew, and beat upon that house; and it fell: and great was the fall of it.
The parable of the mustard seed:
Mt: 13:31: Another parable put he forth unto them, saying, The kingdom of heaven is like to a grain of mustard seed, which a man took, and sowed in his field:
Mt: 13:32: Which indeed is the least of all seeds: but when it is grown, it is the greatest among herbs, and becometh a tree, so that the birds of the air come and lodge in the branches thereof.
The parable of new wine in old bottles:
Mt: 9:17: Neither do men put new wine into old bottles: else the bottles break, and the wine runneth out, and the bottles perish: but they put new wine into new bottles, and both are preserved.
The lesson on forgiveness:
Mt: 18:15: Moreover if thy brother shall trespass against thee, go and tell him his fault between thee and him alone: if he shall hear thee, thou hast gained thy brother.

Figure 10 briefly highlights the preference for Jesus as teacher/Rabbi by historical Jesus scholars.

Figure 10: Some proponents of Jesus as Teacher/Rabbi

\begin{tabular}{l} 
"Whatever else can be said about the pre-Easter Jesus, he was a teacher of wisdom - a sage, as teachers of wisdom \\
are called." (Borg, 1994,: 69) \\
\hline "The picture of Jesus surrounded by disciples makes it evident that he is understood as a teacher and not simply a \\
wandering miracle-worker." (Perkins, 1990: 32 ) \\
\hline "His ethical message was also aimed at all and sundry, as were also his parables, a form of homiletic teaching \\
commonly used by rabbinic preachers.... He several times taught in synagogues and once delivered the liturgical \\
sermon after reading the prophetic lesson of the day in Nazareth." (Vermes, 1973: 27)
\end{tabular}




\subsection{The healer (Type III)}

The following scholars describe or put emphasis on the historical Jesus as healer/holy man /Hasid/shaman/miracle worker: Vermes (1973); Borg (1993); Craffert (2008); Meier (in Willits, 2005). Figure 11 provides some Biblical evidence for Jesus as healer.

Figure 11: Biblical evidence for Jesus as Healer (Type III)

\begin{tabular}{l}
\hline Healing of a demoniac: \\
Mk: 1:23: And there was in their synagogue a man with an unclean spirit; and he cried out, \\
Mk: 1:24: Saying, Let us alone; what have we to do with thee, thou Jesus of Nazareth? art thou come to destroy us? I \\
know thee who thou art, the Holy One of God. \\
Mk: 1:25: And Jesus rebuked him, saying, Hold thy peace, and come out of him. \\
Mk: 1:26: And when the unclean spirit had torn him, and cried with a loud voice, he came out of him. \\
\hline Healing of the sick: \\
Mt: 8:16: When the even was come, they brought unto him many that were possessed with devils: and he cast out the \\
spirits with his word, and healed all that were sick. \\
\hline Healing of a leper: \\
Mt: 8:2: And, behold, there came a leper and worshipped him, saying, Lord, if thou wilt, thou canst make me clean. \\
Mt: 8:3: And Jesus put forth his hand, and touched him, saying, I will; be thou clean. And immediately his leprosy was \\
cleansed. \\
\hline Healing of the centurion's servant: \\
Mt: 8:5: And when Jesus was entered into Capernaum, there came unto him a centurion, beseeching him, \\
Mt: 8:6: And saying, Lord, my servant lieth at home sick of the palsy, grievously tormented. \\
Mt: 8:7: And Jesus saith unto him, I will come and heal him.
\end{tabular}

Figure 12: Some proponents of Jesus as Healer

\begin{tabular}{l} 
"...the safe assumption [is] that Jesus did not belong among the Pharisees, Essenes, Zealots or Gnostics, but was \\
one of the holy miracle-workers of Galilee." (Vermes, 1973: 223) \\
\hline "... we can say that Jesus was perceived by his contemporaries and himself as an exorcist who cast demons out of \\
people and as a healer of diseases, and that this was attributed to the power of the Spirit working through him." \\
(Borg, 1994: 35)
\end{tabular}

\subsection{The Messiah/King (Type IV)}

The following scholars describe or put emphasis on the historical Jesus as messiah/king/ruler:

Strauss (1835); Renan (1863); Schweitzer (1910); Dibelius (1949); Theissen and Winter (in Willits, 2005); Allison (in Willits, 2005); Boccaccini (in Bertalotto, 2010); Allison (in Bertalotto, 2010); Dunn (in Bertalotto, 2010); Evans (in Bertalotto, 2010); Gathercole (in Bertalotto, 2010); Grappe (in Bertalotto, 2010); Oporto (in Bertalotto, 2010); Horsley (in Bertalotto, 2010); McKnight (in Bertalotto, 2010). Figure 13 provides some Biblical evidence for Jesus as Messiah/ King.

Figure 13: Biblical evidence for Jesus as Messiah/King (Type IV)

The cleansing of the Temple:
Jn: 2:13: And the Jews' passover was at hand, and Jesus went up to Jerusalem,
Jn: 2:14: And found in the temple those that sold oxen and sheep and doves, and the changers of money sitting:
Jn: 2:15: And when he had made a scourge of small cords, he drove them all out of the temple, and the sheep, and the
oxen; and poured out the changers' money, and overthrew the tables;
Jn: 2:16: And said unto them that sold doves, Take these things hence; make not my Father's house an house of
merchandise.
Commanding the twelve Apostles:
Mt: 10:5: These twelve Jesus sent forth, and commanded them, saying, Go not into the way of the Gentiles, and into any
city of the Samaritans enter ye not:
Mt: 10:6: But go rather to the lost sheep of the house of Israel.
Mt: 10:7: And as ye go, preach, saying, The kingdom of heaven is at hand.




\begin{abstract}
Triumphal entry into Jerusalem:
Mt: 21:6: And the disciples went, and did as Jesus commanded them,

Mt: 21:7: And brought the ass, and the colt, and put on them their clothes, and they set him thereon.

Mt: 21:8: And a very great multitude spread their garments in the way; others cut down branches from the trees, and strawed them in the way.

Mt: 21:9: And the multitudes that went before, and that followed, cried, saying, Hosanna to the Son of David: Blessed is he that cometh in the name of the Lord; Hosanna in the highest.

Mt: 21:10: And when he was come into Jerusalem, all the city was moved, saying, Who is this?

Commanding the disciples:

Mt: 28:16: Then the eleven disciples went away into Galilee, into a mountain where Jesus had appointed them.

Mt: 28:17: And when they saw him, they worshipped him: but some doubted.

Mt: 28:18: And Jesus came and spake unto them, saying, All power is given unto me in heaven and in earth.

Mt: 28:19: Go ye therefore, and teach all nations, baptizing them in the name of the Father, and of the Son, and of the Holy Ghost:

Mt: 28:20: Teaching them to observe all things whatsoever I have commanded you: and, lo, I am with you always, even unto the end of the world. Amen.
\end{abstract}

Figure 14 briefly highlights the preference for Jesus as Messiah / King of one kind or another, by historical Jesus scholars.

Figure 14: Some proponents of Jesus as Messiah/King

\begin{tabular}{|l|}
\hline "As a charismatic who was also a subversive sage, prophet, and renewal movement founder, Jesus sought a transformation \\
in the historical shape and direction of his social world. (Borg, 1988: 291/292) \\
\hline "He was not teacher, not a casuist; He was an imperious ruler. It was because He was so in His inmost being that He could \\
think of Himself as the Son of Man. That was only the temporally conditioned expression of the fact that He was an \\
authoritative ruler." (Schweitzer, 1948: 404) \\
\hline "He wanted to be some kind of spiritual king, not a physical or political one..." (Beavis, 2004: 103) \\
"Jesus simply spoke openly of the self-consciousness that he had had since the start of his ministry: he had always believed \\
he was both true king and priest and he had acted accordingly." (Crispin, 2007: 79) \\
\hline
\end{tabular}

\title{
4. Conclusion
}

This paper focused on historical Jesus research that is representative of each of the four archetypal orientations of the mind (types I, II, III and IV). For this purpose appropriate Biblical evidence and the ideas of some leading figures in the field of historical Jesus research were briefly surveyed, and found to support the meta-theoretical approach.

The general tendency in the scholarly literature, in which recourse is also taken to how Jesus thought about himself (based on interpretations of canonical and non-canonical source material) and how he was regarded by his contemporaries, indicate four distinct roles or orientations, pointing to him as Prophet (type I), Teacher-Rabbi (type II), Healer (type III), and Messiah/King (type IV).

\section{References}

Allison, D., in: Bertalotto, P., Boccacini, G. and Charlesworth, J. H. (Ed.) (2010) "The historical Jesus: contemporary interpreters and new perspectives," Henoch, Vol. 32, 2, p. 255.

Allison, D., in: Willits, J. (2005) "Pre-suppositions and procedures in the study of the 'historical Jesus' or, why I decided not to be a "historical Jesus; scholar," Journal for the Study of the Historical Jesus, Vol. X, pp. $95-100$.

Beavis, M. A. (2004) "The kingdom of God, utopia and timocracy", Journal for the Study of the Historical Jesus, Vol. 2 (1), pp91-106.

Bertalotto, P., Boccacini, G. and Charlesworth, J. H. (Ed.) (2010) "The historical Jesus: contemporary interpreters and new perspectives," Henoch, Vol. 32, 2, pp. 250 - 330.

Boccaccini, G., in: Bertalotto, P., Boccacini, G. and Charlesworth, J. H. (Ed.) (2010) "The historical Jesus: contemporary interpreters and new perspectives," Henoch, Vol. 32, 2, p. 259.

Borg, M. J. (1988) "A renaissance in Jesus studies," Theology Today, Vol. 45, No.3, pp. 280 - 292.

Borg, M. (1993) "Me and Jesus - the journey home," The Fourth R, Vol. 6, 4, p. 13.

Borg, M. (1994) "Jesus in contemporary scholarship," Pennsylvania: Trinity Press International.

Bird, M. (2006) "The peril of modernizing Jesus and the crisis of not contemporizing the Christ," EQ, Vol. 78, 4, pp. $291-312$.

Bultmann, R. (1934) "Jesus and the Word," New York: Charles Scribner's Sons.

Charlesworth, J. H., in: Bertalotto, P., Boccacini, G. and Charlesworth, J. H. (Ed.) (2010) "The historical Jesus: contemporary interpreters 
and new perspectives," Henoch, Vol. 32, 2, p. 264.

Chilton, B., in: Bertalotto, P., Boccacini, G. and Charlesworth, J. H. (Ed.) (2010) "The historical Jesus: contemporary interpreters and new perspectives," Henoch, Vol. 32, 2, p. 267.

Craffert, P. (2008) "Anthropological historical Jesus research: reflections from the inside," Theologia Viatorum, Vol. 32, (2), pp. 219 268.

Crispin H.T. Fletcher-Louis. (2007) "Jesus as the high priestly messiah: Part 2" Journal for the Study of the Historical Jesus, Vol. 5, 1, pp. 57-79.

Croatto, J. S. (2005) "Jesus, prophet like Elijah, and prophet-teacher like Moses in Luke-Acts," Journal for Biblical Literature, Vol. 124, 3 , pp. $451-465$.

Dibelius, M. (1949) "Jesus," Philadelphia: Westminster Press.

Dunn, J., in: Bertalotto, P., Boccacini, G. and Charlesworth, J. H. (Ed.) (2010) "The historical Jesus: contemporary interpreters and new perspectives," Henoch, Vol. 32, 2, p. 276.

Evans, C. A., in: Bertalotto, P., Boccacini, G. and Charlesworth, J. H. (Ed.) (2010) "The historical Jesus: contemporary interpreters and new perspectives," Henoch, Vol. 32, 2, p. 278.

Evans, C. A. (2011) "Prophet, sage, healer, messiah, and martyr: Types and identities of Jesus." In: Holmen, T. and S. E. Porter (2011), (Ed.) "Handbook for the Study of the Historical Jesus," Leiden: Koninklijke Brill.

Eve, E. (2005) "Meier, miracle and multiple attestation," Journal for the Study of the Historical Jesus, Vol. 3, 1, pp. 23-45.

Freyn, R., in: Bertalotto, P., Boccacini, G. and Charlesworth, J. H. (Ed.) (2010) "The historical Jesus: contemporary interpreters and new perspectives," Henoch, Vol. 32, 2, pp. $281-282$.

Fuller, R. (1994). "Biblical studies 1955-1990," Anglican Theological Review, Vol. 76, Issue 2, pp. 160 - 171.

Gathercole, G., in: Bertalotto, P., Boccacini, G. and Charlesworth, J. H. (Ed.) (2010) "The historical Jesus: contemporary interpreters and new perspectives," Henoch, Vol. 32, 2, p. 284.

Grappe, T., in: Bertalotto, P., Boccacini, G. and Charlesworth, J. H. (Ed.) (2010) "The historical Jesus: contemporary interpreters and new perspectives," Henoch, Vol. 32, 2, p. 286.

Harvey, V. A. (2000) "Jesus and history, the believer and the historian," The Christian Century, pp. 91-94

Holmen, T. and S. E. Porter (2011) "Introduction: The handbook for the study of the historical Jesus in perspective", In: Holmen, T. and S. E. Porter (2011), (Ed.) "Handbook for the Study of the Historical Jesus," Leiden: Koninklijke Brill.

Horsley, R. A. (2008) "Jesus in the new millennium: a review essay," Review of Biblical Literature, pp.1 - 28.

Horsley, R. A., in: Bertalotto, P., Boccacini, G. and Charlesworth, J. H. (Ed.) (2010) "The historical Jesus: contemporary interpreters and new perspectives," Henoch, Vol. 32, 2, p. 291.

Kazen, T. (2008) "The Christology of early Christian practice," Journal for Biblical Literature, Vol. 127, no. 3, pp. 591-614.

Keck, L. E. (1994) "The second coming of the liberal Jesus?" The Christian Century, pp. 784- 787.

Levine, J., in: Bertalotto, P., Boccacini, G. and Charlesworth, J. H. (Ed.) (2010) "The historical Jesus: contemporary interpreters and new perspectives," Henoch, Vol. 32, 2, pp. $300-301$

Loewe, W. P. (2000) "From the humanity of Christ to the historical Jesus," Theological Studies, Vol. 61, Issue 2, pp. 314 - 332.

McGaughy, L. C. (1996) "The search for the historical Jesus: Why start with the sayings?" The Fourth R, Volume 9, 5 - 6, pp.1 - 20.

McKnight, J., in: Bertalotto, P., Boccacini, G. and Charlesworth, J. H. (Ed.) (2010) "The historical Jesus: contemporary interpreters and new perspectives," Henoch, Vol. 32, 2, p306.

Meier, J., in: Willits, J. (2005) "Pre-suppositions and procedures in the study of the 'historical Jesus' or, why I decided not to be a "historical Jesus; scholar," Journal for the Study of the Historical Jesus, Vol. X, pp. $76-82$.

Oporto, F., in: Bertalotto, P., Boccacini, G. and Charlesworth, J. H. (Ed.) (2010) "The historical Jesus: contemporary interpreters and new perspectives," Henoch, Vol. 32, 2, p. 288.

Perkins, R. (1990) "Jesus as Teacher," New York: Cambridge University Press.

Pietersen, H. J. (2011) The Four Types of Knowing -Metaphysical, Scientific, Narrative and Pragmatic: A Meta-Epistemology of Mind, New York: Edwin Mellen Press.

Pietersen, H. J. (2014) The Four Archetypal Orientations of the Mind: Foundational, Experiential, Organizational and Actional, New York: Edwin Mellen Press.

Renan, E. (1863) "The life of Jesus," London: Watts \& Company.

Robinson, J. M. (1959) "A new quest of the Biblical Jesus," London: SCM Press.

Rodríguez , R. (2009) "Authenticating criteria: the use and misuse of a critical method," Journal for the Study of the Historical Jesus, Vol. 7, pp. 152-167.

Sacchi, P., in: Bertalotto, P., Boccacini, G. and Charlesworth, J. H. (Ed.) (2010) "The historical Jesus: contemporary interpreters and new perspectives," Henoch, Vol. 32, 2, p. 317

Sanders, E. P. (1993) "Jesus in historical context," Theology Today, Vol. 50, No. 3, pp. 430-448.

Sanders, E. P., in: Willits, J. (2005) "Pre-suppositions and procedures in the study of the 'historical Jesus' or, why I decided not to be a "historical Jesus; scholar," Journal for the Study of the Historical Jesus, Vol. X, pp. $63-71$.

Schweitzer, A. (1948/1910 b) "The quest of the historical Jesus: A critical study of its progress from Reimarus to Wrede. "Translated by W. Montgomery (1910), Great Britain: A. \& C. Black, Ltd. (1948)

Strauss, D. F. (1860/1835) "The life of Jesus critically examined," Translated from the Fourth German Edition, by Marian Evans, New York: Calvin Blanchard. 
Taylor, G., in: Bertalotto, P., Boccacini, G. and Charlesworth, J. H. (Ed.) (2010) "The historical Jesus: contemporary interpreters and new perspectives," Henoch, Vol. 32, 2, p. 322.

Theissen, G. and Winter, M., in: Willits, J. (2005) "Pre-suppositions and procedures in the study of the 'historical Jesus' or, why I decided not to be a "historical Jesus; scholar," Journal for the Study of the Historical Jesus, Vol. X, pp. 88 - 95.

Van Eck, E., (2009) "A prophet of old: Jesus the "public theologian," HTS Theological Studies, Vol. 66, (1), pp.1-10.

Vermes, G (1983/1973) "Jesus the Jew", London: SCM Press

Willits, J. (2005) "Pre-suppositions and procedures in the study of the 'historical Jesus' or, why I decided not to be a 'historical Jesus; scholar," Journal for the Study of the Historical Jesus, Vol. X, pp. 61-108.

Witherington, B. (1997) "The Wright quest for the historical Jesus," The Christian Century, pp. 1075-1078.

Wright, C., in: Willits, J. (2005) "Pre-suppositions and procedures in the study of the 'historical Jesus' or, why I decided not to be a "historical Jesus; scholar," Journal for the Study of the Historical Jesus, Vol. X, pp. $82-88$. 